\title{
COMPARATIVE ANALYSIS OF WESTERN BALKAN FOR GRANTING STATE AID FOR 2017 WITH RESPECT TO ENVIRONMENTAL SUPPORT: CASE OF SERBIA, ALBANIA AND MACEDONIA
}

\author{
Vladimir Naumovski ${ }^{1}$, Filip Ivanovski ${ }^{1}$, Zoran Šapurić ${ }^{1}$, Dame Dimitrovski ${ }^{2}$ \\ ${ }^{1}$ University American College Skopje, \\ ul. Treta makedonska brigada 60, MK-1000 Skopje, Republic of North Macedonia \\ ${ }^{2}$ Faculty of Mechanical Engineering, "Ss. Cyril and Methodius" University in Skopje, \\ P.O. Box 464, MK-1001 Skopje, Republic of North Macedonia \\ vladimir.naumovski@uacs.edu.mk
}

\begin{abstract}
A b s tra ct: The purpose of the comparative analysis is to present the whole overview of the granting state aid in Serbia, Albania and Macedonia for 2017, based on the data obtained by the annual reports published by the authorities responsible for the area of state aid in the countries named above. The analysis consists of processing such data published in the annual reports of the countries named above, focused the overview of the total state aid granted for 2017 in the countries as well as in what form and for what purpose such aid is granted by the state aid providers. The attempt with this analysis is to process the data through a spreadsheet overview, taking into account different parameters, it is for the purpose to show the focus of each country whose economic sectors were targeted of its support, but also to have an overview of what kind of state aid it is and for what purpose it is granted by the state aid providers in the countries named above. Especial overview is done to realize the amount of state aid granted for projects or activities in the filed of protection of environment. Processing the data of the annual reports, but also through more detailed analysis of the content of such reports, the intention is to find elements that make up what is common and different in terms of how such annual reports are compiled (prepared) by the competent authorities from the countries named above.
\end{abstract}

Key words: environmental support; state aid; macroeconomic indicators; social indicators; environmental projects

\section{КОМПАРАТИВНА АНАЛИЗА НА ДОДЕЛЕНАТА ДРЖАВНА ПОМОШ ЗА ЗАЧУВУВАЊЕ НА ЖИВОТНАТА СРЕДИНА ВО 2017 ГОДИНА ВО ЗЕМЈИТЕ ОД ЗАПАДЕН БАЛКАН: СРБИЈА, АЛБАНИЈА И МАКЕДОНИЈА}

А п с т р а к т: Доделувањето државна помош е еден од начините на кои владите се обидуваат да ја помогнат домашната економија. Областите во кои таа помош се доделува се индикатор за приоритетите во кои државата сака да се развива, или пак на кои гранки од економијата сака да им ја зголеми конкурентноста. Целта на оваа компаративна анализа е да се направи преглед на доделените средства како држвна помош во Србија, Албанија и Македонија во 2017 година, споредено со претходните две години. Оваа анализа се базира на податоците дадени во годишните ивзештаи од институциите одговорни за делот на државна помош во земјите кои се погоре наведени. Анализата се состои од обработката на презентираните податоци во годишните извештаи на трите земји, фокусирана е на вкупната помош доделена во секоја земја во 2017 година, како и на формата и целта на таа државна помош од страна на давателите. Во овој труд се прави обид да се обработат податоците преку соодветни табели и графици земајќи предвид различни параметри, со цел да се прикаже фокусот на секоја земја одделно од аспект на тоа кој сегмент од економијата е цел на поддршката. Трудот исто така се обидува да прикаже каков тип државна помош е обезбеден од нејзините даватели и со која цел, за секоја од наведените држави одделно. Посебен преглед е направен со цел да се утвдри колку од дадената државна помош е за проекти и активности во делот заштита на животната средина. Преку обработката на податоците од годишните извештаи, но и преку подетални анализи на содржината на тие извештаи, трудот има интенција да идентификува што е заедничко, а што различно во подготовката на извештаите и колку тие се соодветно подготвени за анализа од компетентни институции во секоја од земјите.

Клучни зборови: поддршка на животната средина; државна помош; макроекономски индикатори; социјални индикатори; проекти за животна средина 


\section{CHARACTERISTICS AND SHORT DESCRIPTION OF THE ANNUAL REPORT FOR EACH COUNTRY SEPARATELY}

\subsection{Serbia}

Every state aid provider is required to submit prescribed data for the granted state aid or to prepare the annual report to the Ministry of Finance in the form of prescribed tables for state aid. The only exception to this rule is the Ministry of Agriculture, Fisheries and Forestry that gives data only for the total amount of the granted state aid because the provisions of the State Aid Control Act do not apply to agricultural products and fisheries. Meaning the aid in the agricultural sector is not analyzed separately, but it is stated in the total amount of the granted aid. The table for state aid contains data for: the providers and the users of the state aid, the economic sector, number of decision of the commission, title of the state aid measure, legal basis for granting state aid, type, amount and instrument of state aid, source of funding, duration and the purpose of the state aid.

The total amount of the granted state aid for 2017 is 807.3 million EUR, which is 5\% more than the total allocated state aid for 2016 (767 million EUR) and is $6 \%$ less than the granted state aid for 2015 (863.1 million EUR).

\subsection{Albania}

The annual report for granting state aid for 2017 is prepared by the Directorate of Economy and Development Policy, which is a part of the Ministry of Finance and Economy, and the State Aid Commission. Although, this report is applicable for 2017 it provides data for the period 2014-2017, making comparison between the state aid on national level and the stated aid provided in the states of the European Union during these years. When preparing the annual report on how to present and analyze the data it is stated that the methodology of the European Commission is followed. The report describes the main goals achieved in the field of the state aid in Albania, as well as the main instruments used in the period 2014-2017. As main instruments of state aid in the period 2014-2017 are mainly grants and tax exemptions, reimbursement or reduction of the tax rate. Depending on the strategic goals and priorities of industrial policy development in the country, in the short-term and mid-term there is an opportunity to change the models for determination the aid schemes. However, with the annual report is stated that the intention is to point out the importance of the scheme preparation based on many years of development and the key to achieve influential goals in many economic sectors in the country. The amount of the state aid granted by the providers of state aid during 2014-2017 is 82.28 million EUR in total, of which 16.88 million EUR are granted during 2017. In the total amount of the aid granted for 2017 is stated that the main share (about $63.1 \%$ ) consists of support towards the economic sectors unlike the countries in EU where 94\% of the total aid is provided in the categories of aid to achieve horizontal goals ("positive aid"). The state aid for the industry and services includes the category for horizontal aid (aid for research - development and innovation, aid for small and mediumsized enterprises, employment aid, training aid, operational aid, sport aid, cultural aid) and sectorial aid (aid for public transport, aid for public service, aid for mining, the aid for energy sector, aid for tourism). The state aid is provided by the use of several instruments, such as: subsidies and grants (A1), tax exemption, tax deferral, reduction of tax rate or deducting social security contributions (A2).

\subsection{Macedonia}

The annual report for 2017 is prepared by the Commission for Protection of Competition based on the data obtained from the state aid providers who have a legal obligation to submit an annual report to the Commission for Protection of Competition by March $1^{\text {st }}$ of the current year for the granted allowed state aid in the previous year. In the annual report for 2017 in addition to state aid data, the report contains data on the competition - this is because of the fact that the Commission for Protection of Competition as an independent state authority has legal competences for both areas mentioned above.

The annual state aid report consists of information on the state aid legislative framework and methodological principles that need to be fulfilled in order for a measure to present a state aid, then information on granting regional investment aid and granted state aid which is different from the regional aid, determination of financial instruments, information on the number of adopted solutions on the approved state aid in 2017 as well as the number of adopted opinions in the same year, the type and the total amount of state aid, etc. The state aid data indicates that the state aid was largely granted to support projects that have a direct impact on the deve- 
lopment of the economy in the country, and especially through the implementation of projects that eliminate the difficulties in the domestic economy and promotes the realization of projects of significant economic interest to the country. But, it is also about emphasizing the role of the country through the mechanism of the state aid in support and development of the tourism, the creation of active programs and measures for training and employment of unemployed people, environmental protection, support of small and medium-sized enterprises, implementation of industrial policy and support and development of cluster association.

In the annual report, the Table 1 shows the total amount of the planned/approved state aid for 2017 in different categories denominated in euros. The total amount of approved state aid for 2017 is $18,630,807$ EUR. This amount is notified by the state aid providers and approved by the measures that the Commission for Protection of Competition approves as planned allowed state aid. Additionally, the annual report contains data on the total amount of de-minims aid which is 12,141,530 EUR. Then the annual report also contains data on the granted regional aid in amount of 14,301,873 EUR. From the mentioned above, the total granted state aid for 2017 is $29,686,187$ EUR.

\section{Table 1}

Overview of total granted state aid to each country separately as well as the state aid participation in GDP to each country separately

\begin{tabular}{lccc}
\hline \hline & Serbia & Albania & Macedonia \\
\hline Total granted state aid & & & \\
2017 (in mil. EUR) & $807.3 / 574.5$ & 166.88 & 29,686 \\
GDP (\%) & & & \\
\hline \hline
\end{tabular}

In the explanatory part of the annual report for Serbia, it is stated that the amount of 807.3 million EUR also includes the aid provided by the Ministry of Agriculture, Fisheries and Forestry although the provisions of the State Aid Control Act do not apply to agricultural products and fisheries. So, the aid in the agricultural sector is not analyzed separately, but it is a practice to be stated in the total amount. Such granted aid in the field of agriculture, hunting, forestry and fishing is 232.8 million EUR. If this amount of 232,8 million EUR is deducted from the total amount of 807,3 million EUR, then the total granted state aid for 2017 is 574.5 million EUR. Same is the percentage of GDP which amounts to $2 \%$ of 807.3 million EUR (including the amount in the field of agriculture and fisheries). Excluding the amount of 232.8 million EUR allocated in the field of agriculture, hunting, forestry and fishing, i.e. to the amount of 574.5 million EUR the state aid participation in GDP is $1.6 \%$.

\section{A MORE DETAILED EXPLANATION OF THE CONTENT OF THE ANNUAL REPORT IN EACH COUNTRY SEPARATELY}

\subsection{Serbia}

As it is stated above, the total amount of a granted state aid for 2017 is 807.3 million EUR which is $5 \%$ more than the total distributed state aid for 2016 (767 million EUR) and it is $6 \%$ less than the granted state aid for 2015 (863.1 million EUR).

\subsubsection{State aid in Serbia regarding macroeconomic parameters}

Regarding the granted state aid to the macroeconomic indicators (the participation of state aid in GDP, the participation of state aid in public expenditure, a state aid per employee as well as a state aid per capita), the same is illustrated in the Table 2 which have been modified by excluding the columns in which the amount is in dinars and by leaving only the columns in which the amount is in euros.

From the shown in the Table 2, it can be seen that the participation of the state aid in GDP in 2017 is $2.15 \%$, while in 2016 the participation in GDP is $2.20 \%$ and in 2015 is $2.58 \%$. From this it can be concluded that the participation of the total state aid in GDP in 2016 and 2017 declines slightly compared to 2015. In public expenditure the contribution of state aid in 2015 and 2016 is $5.65 \%$ and $4.86 \%$ while the contribution of state aid in 2017 is $5.0 \%$.

In terms of the total granted state aid by category or by the type of the state aid, it is illustrated in Table 3, which is modified by removing the columns in which the amount of the state aid is stated in dinars, and leaving the columns in which the amount according to the criterion above is shown in euros. 
Table 2

State aid vs. macroeconomic parameters in Serbia

\begin{tabular}{|c|c|c|c|}
\hline \multirow[t]{2}{*}{ Indicator (meas. unit) } & 2015 & 2016 & 2017 \\
\hline & 863 & 750 & 792 \\
\hline GDP & 33,491 & 34,142 & 36,838 \\
\hline State aid in GDP $(\%)$ & 2.58 & 2.20 & 2.15 \\
\hline Public expenditure & 15,273 & 15,430 & 15,833 \\
\hline State aid in public expenditure $(\%)$ & 5.65 & 4.48 & 5.0 \\
\hline Employees (number) & $1,896,000$ & $1,914,000$ & $1,977,00$ \\
\hline State aid per employee (EUR) & 455 & 392 & 400 \\
\hline State aid by population (number) & $7,076,372$ & $7,040,272$ & $7,020,858$ \\
\hline State aid by population (EUR) & 122 & 107 & 113 \\
\hline
\end{tabular}

Table 3

Total granted state aid in Serbia for 2015-2016-2017 by categories (EUR /\%)

\begin{tabular}{|c|c|c|c|}
\hline Category & 2015 & 2016 & 2017 \\
\hline Agriculture & $185.0 / 21.4$ & $202.6 / 25.0$ & $232.8 / 27.4$ \\
\hline Industry and services & $678.0 / 78.6$ & $564.4 / 75.1$ & $574.5 / 72.6$ \\
\hline Horizontal state aid & $305.9 / 35.5$ & $249.4 / 33.2$ & $254.0 / 32.1$ \\
\hline Employment & $21.8 / 2.5$ & $29.9 / 4.0$ & $37.19 / 4.7$ \\
\hline SMEs & $0.5 / 0.1$ & I & $0.02 / 0.0$ \\
\hline Environmental protection & l & $16.8 / 2.2$ & $65.43 / 8.3$ \\
\hline Culture and information & $83.9 / 9.7$ & $96.7 / 12.0$ & $13.66 / 1.7$ \\
\hline Remediation and restructuring & $195.2 / 22.6$ & $99.0 / 13.2$ & $19.6 / 2.5$ \\
\hline The rest* & $4.7 / 0.5$ & $7.0 / 0.9$ & $118.11 / 14.9$ \\
\hline Sectorial state aid & $113.8 / 13.2$ & $97.0 / 12.8$ & $74.7 / 9.4$ \\
\hline Mining & $37.0 / 4.3$ & $48.5 / 6.4$ & $37.9 / 4.7$ \\
\hline Traffic & $76.8 / 8.9$ & $48.3 / 6.4$ & $36.8 / 4.7$ \\
\hline Regional state aid & $285.5 / 29.9$ & $218.0 / 29.0$ & $245.8 / 31.1$ \\
\hline TOTAL & $863.1 / 100$ & $767.0 / 100$ & $807.3 / 100$ \\
\hline
\end{tabular}

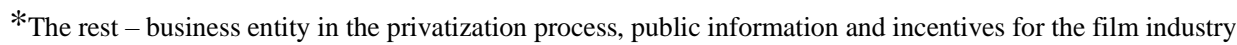

From the data in the table it can be seen that in 2017 the agricultural sector received state aid in the amount of 232.8 million EUR, contributing with $27.4 \%$ in the total distributed state aid. The state aid granted to the industry and the services in 2017 is in the amount of 574.5 million EUR, contributing with $72,6 \%$ in the total granted state aid. The horizontal aid in 2017 is in the total amount of 254.0 million EUR, contributing with $32.1 \%$ in the total distributed state aid.
In 2017 the sectorial state aid is in the amount of 74.7 million EUR and it contributes with $9.4 \%$ in the total granted state aid. It has declined in comparison to the two previous reports, especially compared to 2015. The sectorial state aid data includes the sectors that are designated as specific in European legislation/regulation (mining, transport and steel). The state aid granted in the transport sector in total amount in 2017 is lower compared to the two previous years. In the previous period of reporting, 
the funds were granted to A.D. "Železnice Srbije". However, after the division of the A.D. "Železnice Srbije" into three different economic entities ("Infrastruktura Železnica Srbije" a.d., "Srbija kargo" a.d. and "Srbija voz" a.d.) the state aid in the sector in 2017 applies only to "Srbija voz" a.d. entrusted with the performance of the services of general economic interest - passenger transport.

The regional state aid in 2017 is in the amount of 245.8 million EUR and contributes with $31.1 \%$ in the total granted state aid. From the aspect of the total amount it increases slightly in percentage share compared although such aid is still lower than the total amount in 2015. In the report it is stated that the regional state aid for 2017 is distributed through the instrument subsidies, tax relief, loans under favorable terms granted by the Development Fund of Republic of Serbia.

The aid for remediation and restructuring in 2017 is in the amount of 19.60 million EUR contributing with $2.5 \%$ in the total distributed state aid. This aid in 2017 is significantly lower than two previous years, especially compared to 2015 .

Table 3 also shows the difference in financial amount and percentage in 2015-2016 compared to 2017 for the other different categories of state aid. According to the data shown in the Table 3, the horizontal state aid for 2017 is slightly higher compared to the aid in 2016 and compared to 2015 is significantly lower. Within this aid the amount that is higher is in the area of environmental protection which in 2017 is almost 4 times higher than in 2015. The big difference in the state aid granted for environmental protection for 2017 compared to the state aid granted to the same area for 2016 is due to the approved feed-in tariff aid. The state aid for environmental protection is more distributed through the instruments of subsidies. Also, in the area of employment there is a significant increase in the granted state aid for 2017 compared to the aid in 2016 and especially such an increase in the amount and the percentage for 2017 accentuates if compared to the state aid granted for employment for 2015. The state aid for employment can be seen from the data given in the table to show constant increase. In the report it is stated that this aid is mostly realized by using the tax relief instrument.

The state aid granted for 2015-2016-2017 without taking into account the amount allocated to the field of agriculture and transport is given in the Table 4.

From the above, it can be seen that the state aid (excluding the agricultural and transport sector) for
2017 is 538 million EUR and includes $1.5 \%$ of GDP. The granted state aid includes the same percentage of GDP for 2016 of the granted amount of 516.1 million EUR while the amount of aid for 2015 is 601.5 million EUR and includes $1.8 \%$ of GDP.

\section{Table 4}

The granted state aid (excluding the agricultural and transport sector)

\begin{tabular}{lcccc}
\hline \hline Indicator & Measurement unit & 2015 & 2016 & 2017 \\
\hline State aid & Mil. EUR & 601.5 & 516.1 & 538 \\
GDP & Mil. EUR & 33.492 & 34.142 & 36.838 \\
State aid in GDP & In \% & 1.8 & 1.5 & 1.5 \\
\hline \hline
\end{tabular}

The state aid granted for 2015-2016-2017 without taking into account the amount allocated only to the area of agriculture is given in the Table 5.

Table 5

The granted state aid

(excluding agricultural sector)

\begin{tabular}{lcccc}
\hline \hline Indicator & Measurement unit & 2015 & 2016 & 2017 \\
\hline State aid & Mil. EUR & 678.3 & 564.31 & 537.7 \\
GDP & Mil. EUR & 33.491 & 34.142 & 36.838 \\
State aid in GDP & $\%$ & 2.0 & 1.7 & 1.6 \\
\hline \hline
\end{tabular}

From Table 5 it can be seen that the contribution of the state aid in GDP granted to the industry and services sector in 2017 is $1.6 \%$ which is less than 2015 and 2016 when the contribution in GDP was $2.0 \%$ and $1.7 \%$ respectively.

\subsubsection{Structure of instruments for the state aid granted in 2017}

Generally, the horizontal and regional objectives are financed by direct instruments (subsidies) and indirect instruments (tax reliefs) in the allocation of state aid.

In the annual report for 2017 is stated that the most common instrument for granting state aid are the subsidies contributing with $66.8 \%$ of the total distributed state aid which are mainly granted to stimulate the objectives in the agriculture and the objectives in the industry and services. 
The tax reliefs as an instrument in 2017 contribute with $27 \%$ of the total distributed state aid, and include incentives granted under the legal entities' corporate profit tax law and citizens' corporate income tax law - through lowering the citizens' income tax based on investments in fixed assets.

The loans on favorable terms are represented by $1.6 \%$ of the total distributed state aid for 2017 and represent an increase of $0.5 \%$ compared to 2016. These instruments imply granting loans at favorable interest rates.

The guarantees as a state aid instrument are $0.1 \%$ of the total amount of state aid for 2017 .

\subsubsection{Granting state aid of minor importance (de minims aid)}

In the brief description of the annual report of each country separately, among the other, for Serbia is stated that the granting of de minims aid is followed separately from other state aid and is not shown in the total amount of the granted state aid. The total granted state aid of minor importance for 2017 is 4.199 million dinars and compared to 2016 when de minims aid was 1.336 million dinars it is increased by 3.14 times. ( $1 \mathrm{EUR}=118$ dinars)

Also, it is important to state that Serbia provides annual reports for the granted state aid starting with the reports from 2003 and 2004 while the first report is based on the established legislation is Report for state aid for 2010.

\subsubsection{State aid for environmental projects in Serbia}

The state aid granted in Serbia in the area of environmental protection in 2017 is almost 4 times higher than in 2016. Such huge difference in the amount of state aid granted for environmental protection in 2017 in comparison with the state aid granted for the same purpose in 2016 is a result of the approved aid for the feed-in tariffs. The Report indicates that the state aid for environmental protection is mostly distributed through the instrument of subsidies. The total amount of state aid granted for environmental protection in 2017 equals EUR 65.43 million, or $8.3 \%$ of the total state aid granted.

\subsection{Albania}

As it is stated above, the amount of the state aid granted by the state aid providers during 2014 2017 is 82.28 million EUR of which 16.88 million
EUR are granted during 2017. In 2014 the amount of the granted state aid is 23.22 million EUR, in 201527.19 million EUR, while in 2016 the amount is 12.71 million EUR.

In terms of the granted state aid based on certain socio-economic indicators for the period 20142017, it is illustrated in Table 6, which is modified by removing the columns in which the amount of the state aid is stated in the currency LEK and stating only the data in which the amounts are shown in euros (1 EUR = 123 LEK).

\section{Table 6}

The state aid based on certain socio-economic indicators for the period 2014-2017

\begin{tabular}{lcccc}
\hline \hline Indicators (unit) & 2014 & 2015 & 2016 & 2017 \\
\hline $\begin{array}{l}\text { State aid } \\
\text { (mil. EUR) }\end{array}$ & 23.22 & 27.19 & 12.71 & 16.88 \\
$\begin{array}{l}\text { State aid level } \\
\text { GDP (\%) }\end{array}$ & 0.23 & 0.26 & 0.11 & 0.14 \\
$\begin{array}{l}\text { Expenses from the } \\
\text { state budget - aid } \\
\text { level (\%) }\end{array}$ & 0.74 & 0.86 & 0.38 & 0.47 \\
$\begin{array}{l}\text { Employees } \\
\text { (number) }\end{array}$ & 925,000 & 973,000 & $1,157,210$ & $1,160,506$ \\
$\begin{array}{l}\text { Population } \\
\text { (number) }\end{array}$ & $2,885,792$ & $2,875,592$ & $2,876,591$ & $2,878,977$ \\
\hline \hline
\end{tabular}

Table 6 provides data on total state aid for the period 2014-2017 compared to some indicators. The state aid in absolute value granted in 2017 is increased by $31 \%$ compared to 2016 . GDP level of state aid increased from $0.11 \%$ in 2016 to $0.14 \%$ in 2017 and it is illustrated by years in the following graph (Figure 1).



Fig. 1

The annual report for 2017 provides information on the state aid in Albania in relation to 28 member state of EU for 2015 and 2016 (Table 7). The table includes data published by the European Commission with the exception of the aid provided 
by the member states in the field of transport and to deal with the economic crisis.

Ta b le 7

The state aid in Albania compared to the member states of the European Union

\begin{tabular}{|c|c|c|c|c|}
\hline State & $\begin{array}{l}\text { Year } \\
2015\end{array}$ & $\begin{array}{l}\text { Rate } \\
\text { to GDP }\end{array}$ & $\begin{array}{l}\text { Year } \\
2016\end{array}$ & $\begin{array}{l}\text { Rate } \\
\text { to GDP }\end{array}$ \\
\hline Albania & 27.19 & 0.26 & 12.71 & 0.11 \\
\hline $\begin{array}{l}\text { EU ( } 28 \text { member } \\
\text { countries) }\end{array}$ & $93,590.10$ & 0.63 & $97,298.80$ & 0.65 \\
\hline Belgium & $1,985.00$ & 0.48 & $2,420.50$ & 0.57 \\
\hline Bulgaria & 330.60 & 0.73 & 293.40 & 0.61 \\
\hline Czech Republic & $1,935.00$ & 1.15 & $2,300.30$ & 1.30 \\
\hline Denmark & $3,279.40$ & - & $4,435.60$ & - \\
\hline Germany & $25,799.50$ & - & $39,939.80$ & - \\
\hline Estonia & 193.90 & 0.95 & 172.50 & 0.82 \\
\hline Ireland & 426.80 & 0.16 & 392.40 & 0.14 \\
\hline Greece & $2,191.60$ & 1.24 & 630.40 & 0.36 \\
\hline Spain & $2,223.50$ & 0.21 & $2,284.20$ & 0.20 \\
\hline France & $15,652.20$ & 0.71 & $13,935.20$ & 0.63 \\
\hline Croatia & 262.40 & 0.60 & 436.10 & 0.95 \\
\hline Italy & $3,007.10$ & 0.18 & $2,994.20$ & 0.18 \\
\hline Cyprus & 120.40 & 0.68 & 119.60 & 0.66 \\
\hline Latvia & 536.10 & 2.20 & 363.30 & 1.46 \\
\hline Lithuania & 298.50 & 0.80 & 323.20 & 0.84 \\
\hline Luxembourg & 149.10 & 0.29 & 144.50 & 0.27 \\
\hline Hungary & $1,291.60$ & 1.17 & $2,213.70$ & 1.95 \\
\hline Malta & 91.60 & 0.99 & 54.20 & 0.55 \\
\hline Netherlands & $1,771.70$ & 0.28 & $1,816.10$ & 0.26 \\
\hline Austria & $1,788.00$ & 0.52 & $1,844.80$ & 0.52 \\
\hline Poland & $3,373.80$ & 0.78 & 4.313 .40 & 1.01 \\
\hline Portugal & 872.50 & 0.49 & 621.80 & 0.34 \\
\hline Romania & $1,228.80$ & 0.77 & $1,029.40$ & 0.61 \\
\hline Slovenia & 422.60 & 1.09 & 300.90 & 0.74 \\
\hline Slovakia & 409.50 & 0.52 & 360.90 & 0.44 \\
\hline Finland & $1,568.10$ & 0.75 & $1,646.60$ & 0.76 \\
\hline Sweden & $3,167.50$ & 0.71 & $3,610.20$ & 0.78 \\
\hline United Kingdom & $9,214.20$ & 0.35 & $8,301.60$ & 0.35 \\
\hline
\end{tabular}

The aid includes the costs incurred by each member state that is oriented towards the achievement of horizontal goals of mutual interest, than on the aid provided to various sectors of the economy, such as the transport, as well as the aid to achieve specific goals, such as rescue and restructuring of enterprises, aid for closing down enterprises, excluding the aid for the railway sector.

In the annual report for 2017 it is stated that according to the European Union methodology the state aid is divided in two categories: horizontal state aid and sectorial state aid.

The horizontal state aid is provided to many users without any preferences for any economic activity, economic enterprises, products or services minimizing the effects on the competition.

The sectorial state aid is granted for specific activities and sectors with a greater impact on the market competition.

The total granted state aid by categories is illustrated in Table 8 and Graph 1, which has been modified by removing the columns in which the amount of the state aid is written in currency LEK and stating only the data in which the amounts are shown in euros ( 1 EUR $=123$ LEK).

Table 8

Total granted state aid by categories for 2014-2017 (mil. EUR /\%)

\begin{tabular}{lcccc}
\hline \hline Category & $\mathbf{2 0 1 4}$ & $\mathbf{2 0 1 5}$ & $\mathbf{2 0 1 6}$ & $\mathbf{2 0 1 7}$ \\
\hline $\begin{array}{l}\text { Horizontal } \\
\text { aid }\end{array}$ & $\mathbf{1 5 . 2 6 / 6 5 . 7}$ & $\mathbf{2 0 . 6 0} / 75.8$ & $\mathbf{6 . 1 1} / \mathbf{4 8 . 1}$ & $\mathbf{6 . 2 3 / 3 6 . 9}$ \\
$\begin{array}{l}\text { Employ- } \\
\text { ment }\end{array}$ & $1.07 / 4.6$ & $2.07 / 7.6$ & $1.36 / 10.7$ & $1.48 / 8.7$ \\
Training & $0.78 / 3.40$ & $0.99 / 3.7$ & $2.06 / 16.20$ & $2.08 / 12.3$ \\
Sport & $4.60 / 19.80$ & $14.95 / 55.0$ & $1.23 / 9.7$ & $1.64 / 9.7$ \\
Culture & - & $0.30 / 1.1$ & $0.82 / 6.5$ & $0.30 / 1.8$ \\
$\begin{array}{l}\text { Operational } \\
\text { aid }\end{array}$ & $5.97 / 25.7$ & $0.28 / 1.0$ & - & $0.04 / 0.2$ \\
R\&D\&I & $2.57 / 11.1$ & $1.80 / 6.6$ & $0.14 / 1.1$ & $0.35 / 2.0$ \\
SME & $0.27 / 1.2$ & $0.21 / 0.8$ & $0.49 / 3.9$ & $0.36 / 2.1$ \\
$\begin{array}{l}\text { Sectorial } \\
\text { aid }\end{array}$ & $\mathbf{7 . 9 6 / 3 4 . 3}$ & $\mathbf{6 . 5 9 / 2 4 . 2}$ & $\mathbf{6 . 5 9 / 5 1 . 9}$ & $\mathbf{1 0 . 6 5 / 6 3 . 1}$ \\
$\begin{array}{l}\text { Public } \\
\text { transport }\end{array}$ & $3.14 / 13.5$ & $3.20 / 11.8$ & $2.88 / 22.7$ & $3.00 / / 17.8$ \\
$\begin{array}{l}\text { Public } \\
\text { service }\end{array}$ & $3.21 / 13.8$ & $3.12 / 11.5$ & $3.17 / 24.9$ & $7.32 / 43.3$ \\
Energy & $1.39 / 6.0$ & - & - & - \\
Mines & $0.21 / 0.9$ & $0.27 / 1.0$ & $0.29 / 2.3$ & $0.26 / 1.6$ \\
Tourism & - & - & $0.25 / 2.0$ & $0.07 / 0.4$ \\
\hline TOTAL & $\mathbf{2 3 . 2 2}$ & $\mathbf{2 7 . 1 9}$ & $\mathbf{1 2 . 7 1}$ & $\mathbf{1 6 . 8 8}$ \\
\hline \hline
\end{tabular}




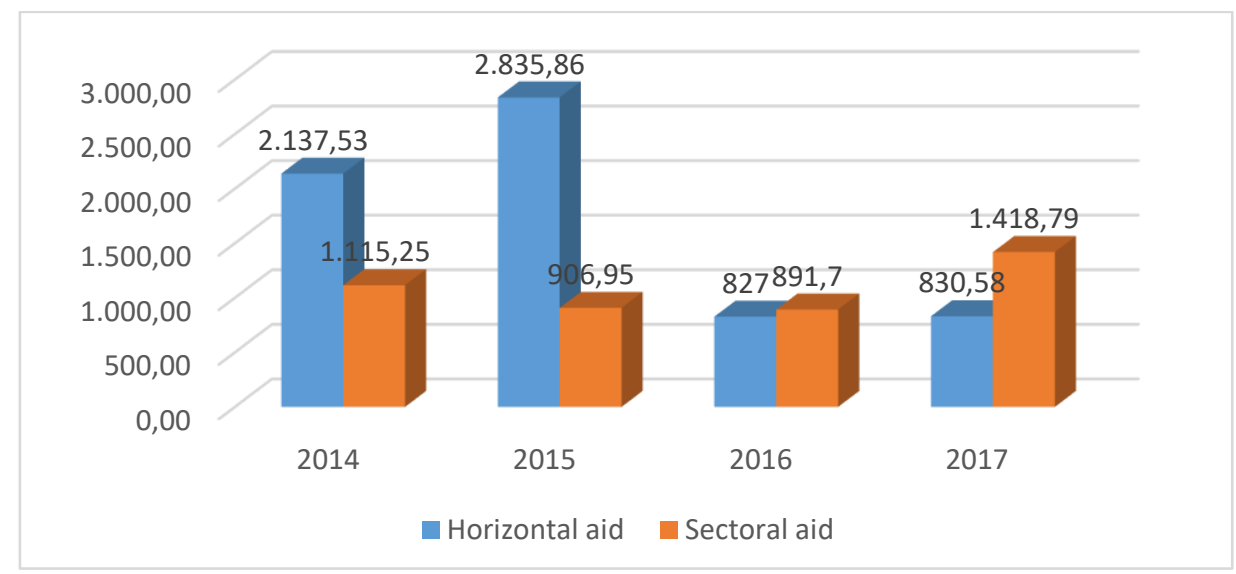

Graph 1

Blue color (horizontal aid) - the amounts are in the currency LEK

Red color (sectorial aid) - the amounts are in the currency LEK

The data from the Table 8, also shown in the Figure 2, show that in 2017 the sectorial state aid constitutes the largest portion of the state aid in total amount of $63.1 \%$ while the horizontal aid is $36.9 \%$.

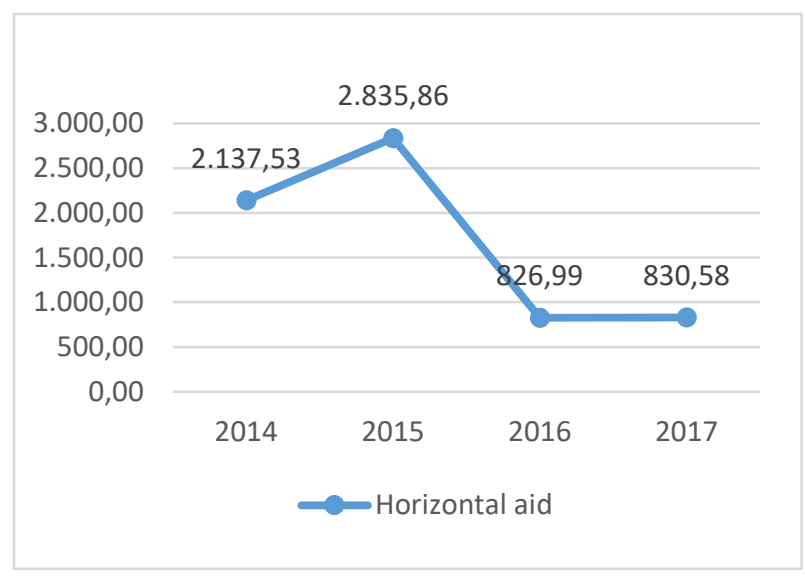

Fig. 2

In nominal amount, the total state aid funds in 2017 increased by $31 \%$ compared to the total assets in 2016. This overall change is due to the factors such as: (1) increasing the state aid for employment; (2) reducing the state aid for training; (3) increasing the state aid for sports support; (4) granted state aid for culture; (5) increasing the operational aid; (6) increasing the state aid for research and development; (7) reducing the state aid to SMEs; (8) increasing state aid for rail transport; (9) increasing the state aid for public service (water supply); (10) reducing the state aid for mines; (11) reducing the state aid to support tourism.

From the Table 9, also it can be seen that in 2017 the horizontal state aid in absolute value is 6.23 million euros. The aid for training constitutes most of this aid category, in total $12.3 \%$.
Ta ble 9

Horizontal state aid (mil. EUR/\%)

\begin{tabular}{lrrrr}
\hline \hline Category & \multicolumn{1}{c}{$\mathbf{2 0 1 4}$} & \multicolumn{1}{c}{$\mathbf{2 0 1 5}$} & $\mathbf{2 0 1 6}$ & \multicolumn{1}{c}{$\mathbf{2 0 1 7}$} \\
\hline $\begin{array}{l}\text { Horizontal } \\
\text { aid }\end{array}$ & $\mathbf{1 5 . 2 6 / 6 5 . 7}$ & $\mathbf{2 0 . 6 0 / 7 5 . 8}$ & $\mathbf{6 . 1 1 / 4 8 . 1}$ & $\mathbf{6 . 2 3 / 3 6 . 9}$ \\
Employment & $1.07 / 4.6$ & $2.07 / 7.6$ & $1.36 / 10.7$ & $1.48 / 8.7$ \\
Training & $0.78 / 3.40$ & $0.99 / 3.7$ & $2.06 / 16.20$ & $2.08 / 12.3$ \\
Sport & $4.60 / 19.80$ & $14.95 / 55.0$ & $1.23 / 9.7$ & $1.64 / 9.7$ \\
Culture & - & $0.30 / 1.1$ & $0.82 / 6.5$ & $0.30 / 1.8$ \\
Operational & $5.97 / 25.7$ & $0.28 / 1.0$ & - & $0.04 / 0.2$ \\
aid & & & & \\
R\&D\&I & $2.57 / 11.1$ & $1.80 / 6.6$ & $0.14 / 1.1$ & $0.35 / 2.0$ \\
SME & $0.27 / 1.2$ & $0.21 / 0.8$ & $0.49 / 3.9$ & $0.36 / 2.1$ \\
\hline \hline
\end{tabular}

Also, the graph illustrates the progress of the horizontal aid during 2014-2017 with amounts given in LEK.

As it is mentioned above, the horizontal aid in 2017 is 6.23 million EUR (830.58 million LEK). The report gives a detailed explanation of each type of horizontal aid based on what is being granted, giving the following:

The aid for employment is provided through 6 schemes for state aid. The schemes are approved by a decision of the State Aid Commission:

1. Decision of the State Aid Commission no. 9 from 2. 2. 2007 on the state aid granting plan for the amount of funding, criteria and the procedure for implementing the internship program for unemployed job seekers who have completed higher education in the country or abroad.

2. Decision of the State Aid Commission no. 11 from 15. 3. 2007 on the existing scheme for the employment promotion program for job seekers. 
3. Decision of the State Aid Commission no. 38 from 19. 9. 2011 on planned state aid for the promotion program for employment of women from special groups.

4. Decision of the State Aid Commission no. 39 from 19. 9. 2011 on planned state aid for the amount of funding, criteria and the procedure for implementing the employment promotion program for job seekers for the first time.

5. Decision of the State Aid Commission no. 47 from 28. 3. 2014 on planned state aid for the employment promotion program for people with special needs.

6. Decision of the State Aid Control Commission no. 62 from 14. 12. 2015 on planned state aid for the promotion program for employment of orphans.

Based on the aid schemes mentioned above, the annual report provides data on the number of unemployed people who have employed as well as the number of enterprises that have been users of this type of aid in accordance with the approved aid schemes by the State Aid Commission.

The aid for training that is approved by a decision of the State Aid Control Commission no. 12 from 15. 3. 2007 as an existing aid scheme to promote the employment program through job creation, and aims to train job seekers who will later find a job in the company that is user of the state aid. Also, this scheme provides data on the number of users and the trained unemployed people as well as the amount of the aid granted to the enterprises.

Sports aid approved by a decision of the State Aid Control Commission no. 54 from 26. 1. 2015 as an existing aid scheme with a grant from the state budget in the sports sector. For this aid scheme whose main purpose is to promote sports culture, sports education and the physical activities by increasing the participation of the citizens in the sport, in 2017 are allocated 1.64 million EUR from the state budget, whereby various sports federations that provide sports services to their members and the Albanian National Olympic Committee are users of the scheme.

Support for the promotion of culture in 2017 was provided in the form of financial support with public funds for call-based projects and in the implementation of the institutional priorities for the program in the field of arts and culture. The purpose of the aid is to support cultural projects for individuals and entities performing their activities in the field of art and culture in various artistic disciplines such as theater, music, visual arts, research, infrastructure development (capacity building).
Operational aid as a category includes the excise tax compensation for fuels used in heating greenhouses and in the industry.

Research and development aid according to the report of the Directorate General for Taxation, is provided to companies that sign contracts about carbon and their producers, providing VAT exemptions to all contractors and subcontractors for execution research and development of carbon operations. In 2017 it is stated that foreign companies performing carbon operations in Albania used import exemptions (VAT and customs exemptions) in the amount of 0.3 million EUR.

SMEs aid in 2017 is implemented as an aid scheme through the fund AIDA (Albanian Investment Development Agency), but also by the state aid scheme provided by the Municipality of Tirana.

Regarding the sectorial state aid the annual report for 2017 states that it is in the absolute value of 10.65 million EUR, with the participation of this aid in the overall granted state aid for 2017 contributes with $63.1 \%$. In the Table 10 below the amounts are given in euros, while in the graph are given in LEK.

Ta b le 10

Sectorial aid in Albania (mil. EUR/\%)

\begin{tabular}{lcccc}
\hline \hline Category & $2014 / \mathrm{C} / \%$ & 2015 & 2016 & 2017 \\
\hline $\begin{array}{l}\text { Sectorial } \\
\text { aid }\end{array}$ & $7.96 / 34.3$ & $6.59 / 24.2$ & $6.59 / 51.9$ & $10.65 / 63.1$ \\
$\begin{array}{l}\text { Public } \\
\text { transport }\end{array}$ & $3.14 / 13.5$ & $3.20 / 11.8$ & $2.88 / 22.7$ & $3.00 / 17.8$ \\
$\begin{array}{l}\text { Public } \\
\text { service }\end{array}$ & $3.21 / 13.8$ & $3.12 / 11.5$ & $3.17 / 24.9$ & $7.32 / 43.3$ \\
Energy & $1.39 / 6.0$ & - & - & - \\
Mines & $0.21 / 0.9$ & $0.27 / 1.0$ & $0.29 / 2.3$ & $0.26 / 1.6$ \\
Tourism & - & - & $0.25 / 2.0$ & $0.07 / 0.4$ \\
\hline \hline
\end{tabular}

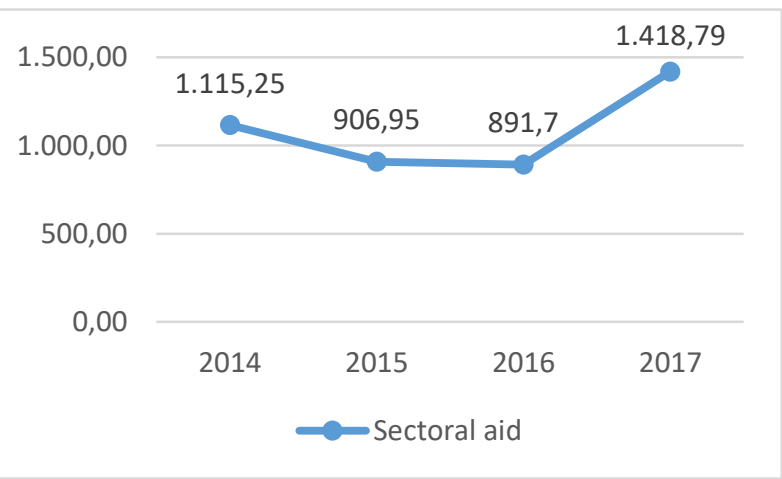

Fig. 3. Sectorial aid 
It can be seen from the Table 10 that for 2017 aid in the amount of 7.32 million EUR has been granted for the public services (aid in the water supply and sewage sector) in the form of subsidies to public utilities, then 3 million EUR are granted for public transport support. 0.26 million EUR have been granted to support mining, and to extend the closure of used and inefficient mines. The tourism sector was supported with aid of 0.07 million EUR through the grant instrument of the "Tourism Support Fund" program where the beneficiaries of this aid are public entities and nonprofit organizations.

The structure of the instruments for the granted state aid in 2017 is shown in Table 11, with the amounts given in the currency LEK ( 1 EUR $=123$ LEK).

\section{Table 11}

The structure of instruments for the granted state aid in 2017 (mil./LEK)

\begin{tabular}{|c|c|c|}
\hline Aid category & $\begin{array}{l}\text { Subsidies } \\
\text { and grants } \\
\text { (A1) }\end{array}$ & $\begin{array}{l}\text { Tax exemption, tax deferral, } \\
\text { tax rate reduction and } \\
\text { deduction of the social } \\
\text { insurance contribution } \\
\text { (A2) }\end{array}$ \\
\hline \multicolumn{3}{|l|}{ Horizontal aid } \\
\hline Employment & 196.79 & \\
\hline Training & 276.98 & \\
\hline Sport & 218.80 & \\
\hline Culture & 39.58 & \\
\hline Operational aid & & 5.02 \\
\hline $\begin{array}{l}\text { Research } \\
\text { development and } \\
\text { innovation }\end{array}$ & & 46.08 \\
\hline SME & 47.33 & \\
\hline \multicolumn{3}{|l|}{ Sectoral aid } \\
\hline $\begin{array}{l}\text { Public transport } \\
\text { (Railway) }\end{array}$ & 400.00 & \\
\hline Public service & 974.90 & \\
\hline Energy & - & \\
\hline Mines & 35.00 & \\
\hline Tourism & 8.89 & \\
\hline TOTAL & $2,198.27$ & 51.10 \\
\hline
\end{tabular}

The total amount of granted state aid according to the instruments A1 and A2 for 2017 is 2,249.37 million LEK or 16.88 million EUR. The instrument A1 contributes $77 \%$ of the total granted state aid while the instrument A2 contributes $23 \%$.

\subsubsection{State aid for environmental projects in Albania}

According to the data provided in the 2017 Annual Report of Albania, no state aid has been granted for environmental protection. Funds in the amount of EUR 260,000 were granted for the mines, i.e. $1.6 \%$ of the total state aid granted. At the same time, state aid in the amount of EUR 7.32 million, i.e. $43.3 \%$ of the total state aid has been granted for public services (aid in the water supply and sewerage segment) in the form of subsidies to utility companies and support of the public transport system (railway transport) for which EUR 3 million were granted, or $17.8 \%$ of the total state aid granted. However, the state aid granted in the above-mentioned categories cannot be strictly considered as state aid for environmental protection, nevertheless, it has an impact and is related to the environment.

\subsection{Macedonia}

As it is stated above the amount of the granted state aid for 2017 is 29,686,187 EUR.

As to the total amount of aid, the annual report consists of two parts:

- The part explaining the decisions adopted by the Commission for Protection of Competition regarding the planned/approved state aid, whereby the total amount of approved state aid is 1,145,794,650 den., or 18,630,807 EUR. This amount is notified by the state aid providers and approved through measures approved by the commission as a planned allowed state aid.

- The part explaining the total granted state aid in 2017 , which is $1,825,700,517$ den., or $29,686,187$ EUR.

The annual report provides data on the number of decision made by the Commission, with a table overview giving a clearer picture about the measures and the programs approved by a decision of the Commission, designed measure. i.e. intended to grant funds for the implementation of the measure or the program, the total amount of planned state aid written in denars and euros as well as for determining the type of aid. 
Table 12

Approved state aid for 2017 in Macedonia

\begin{tabular}{|c|c|c|c|c|}
\hline Number of & Provider & Purpose & The amount in den & The amount in EUR \\
\hline $\begin{array}{l}1 \text { No. } 10-49 \text { from } \\
\text { 8. 2. } 2017\end{array}$ & $\begin{array}{l}\text { Ministry of } \\
\text { Environment } \\
\text { and Physical } \\
\text { Planning }\end{array}$ & $\begin{array}{l}\text { Environmental investment pro- } \\
\text { gram for } 2017\end{array}$ & $5,000,000.00$ & $81,300.81$ \\
\hline $\begin{array}{l}2 \text { No. } 10-20 \text { from } \\
\text { 21. 2. } 2017 \text { de mini- } \\
\text { mis/horizontal aid }\end{array}$ & $\begin{array}{l}\text { Ministry of } \\
\text { Finance }\end{array}$ & $\begin{array}{l}\text { Competitiveness. innovation and } \\
\text { entrepreneurship program for } \\
2017 \text { (support and development } \\
\text { of SMEs) }\end{array}$ & $34,510,000.00 / 1,400,000$ & $561,138.21 / 22,764.23$ \\
\hline $\begin{array}{l}3 \text { No. } 10-20 \text { from } \\
\text { 21. 2. } 2017 \text { de minimis }\end{array}$ & $\begin{array}{l}\text { Ministry of } \\
\text { Finance }\end{array}$ & $\begin{array}{l}\text { Competitiveness. innovation and } \\
\text { entrepreneurship program for } \\
2017 \text { (implementation of indus- } \\
\text { trial policy) }\end{array}$ & $2,500,000.00$ & $40,650.41$ \\
\hline $\begin{array}{l}4 \text { No.10-20 from } \\
\text { 21. 2. } 2017 \text { de minimis }\end{array}$ & $\begin{array}{l}\text { Ministry of } \\
\text { Finance }\end{array}$ & $\begin{array}{l}\text { Competitiveness. innovation and } \\
\text { entrepreneurship program for } \\
2017 \text { (support and development } \\
\text { of cluster association) }\end{array}$ & $5,000,000.00$ & $81,300.81$ \\
\hline $\begin{array}{l}5 \text { No. } 10.17 \text { from } \\
\text { 23. } 5.2017\end{array}$ & $\begin{array}{l}\text { Agency for } \\
\text { Promotion } \\
\text { and Support } \\
\text { of Tourism } \\
\text { of RM }\end{array}$ & $\begin{array}{l}\text { Program for promotion and } \\
\text { support of tourism in RM }\end{array}$ & $116,500,000.00$ & $1,894,308.94$ \\
\hline $\begin{array}{l}6 \text { No.10-16 from } \\
\text { 23. 3. } 2017 \text { de minimis/ } \\
\text { horizontal aid }\end{array}$ & $\begin{array}{l}\text { Employment } \\
\text { agency } \\
\text { of RM }\end{array}$ & $\begin{array}{l}\text { Operational plan for active } \\
\text { employment programs and } \\
\text { measures and labor market } \\
\text { services }\end{array}$ & $\begin{array}{l}704,964,150.00 / \\
192,644,650.00\end{array}$ & $\begin{array}{c}11,458,441.46 / \\
3,132,433.33\end{array}$ \\
\hline $\begin{array}{l}7 \text { No. } 10-50 \text { from } \\
\text { 6. } 9.2017\end{array}$ & $\begin{array}{l}\text { Ministry of } \\
\text { Labor and } \\
\text { Social Policy }\end{array}$ & $\begin{array}{l}\text { Draft Law on Amending the } \\
\text { Minimum Wage Law in RM }\end{array}$ & $\begin{array}{c}369,000,000.00 \text { for } 2017 \\
461,250,000.00 \text { for } 2018 \\
\text { or in total } 830,250,000.00\end{array}$ & $\begin{array}{c}6,000,000.00 \text { for } 2017 \\
7,500,000.00 \text { for } 2018 \\
\text { or in total } 13,500,000.00\end{array}$ \\
\hline Total & & & $1,145,794,650.00$ & $18,630,807.32$ \\
\hline Total de minimis & & & $746,704,105.00$ & $12,141,530.89$ \\
\hline
\end{tabular}

The Table 12 shows that the Commission in 2017 has adopted decisions, with 3 decisions stating that the measures contained in the reports represent state aid, while in the other 4 decisions it is determined that the measures represent aid of minor importance (the minims aid), i.e. granted state aid not exceeding 200,000 EUR for a period of 3 years. The table also contains data on the total amount of the approved de minims aid which is 12,141,531 EUR. The table, in addition to the data on the total amount of the planned state aid, also contains information about the granted state aid in different categories such as: environmental protection, support to small and medium-sized enterprises, implementation of industrial policy, support and development of cluster associations, tourism, employment as well as planned state aid granting based on Draft-law on Amending the Minimum Wage Law in RM.

The annual report also provides data on the number of opinions adopted (11 opinions in total in 2017) by the Commission for Protection of Competition, stating that the trend of opinions adopted by the Commission at the stage of preparation of the legal acts that may contain elements of state aid has increased, as well as the need to evaluate the draft contracts for granting regional aid to potential users. 
The annual report also contains data on the participation of the granted state aid in relation to GDP for the total amount of approved state aid, and which is $0.18 \%$ (of the total amount of $18,630,807$ EUR). The annual report also contains data on the participation of the granted state aid in relation to GDP for already granted state aid, which is $0.29 \%$ (of the total amount of 29,686,187 EUR).
In relation to the granted regional investment state aid during 2017 a spreadsheet explains for what kind of regional aid funds are allocated, but also the amount of the granted regional aid is given in denars (Table 13).

Table 13

The granted regional investment state aid for 2017 (den)

\begin{tabular}{cccccccc}
\hline \hline $\begin{array}{c}\text { Personal } \\
\text { income tax }\end{array}$ & $\begin{array}{c}\text { Personal } \\
\text { profit tax }\end{array}$ & Job creation & $\begin{array}{c}50 \% \text { compulsory } \\
\text { social security } \\
\text { contributions }\end{array}$ & $\begin{array}{c}\text { Costs for } \\
\text { construction } \\
\text { of a building }\end{array}$ & Training & $\begin{array}{c}\text { Duty-free } \\
\text { exemptions }\end{array}$ & Total \\
\hline $132,827,872$ & $21,949,628$ & $379,137,277$ & $217,009,475$ & $92,487,399$ & $6,074,753$ & $27,418,970$ & $879,565,237$ \\
\hline \hline
\end{tabular}

From the Table 13 it can be seen that the total granted regional aid is $14,301,874$ EUR. Part of the funds for this purpose are being allocated in accordance with the approved scheme of the Commission for Protection of Competition on the Law on Technological Industrial Development Zones.

The Table 14 explains the granted state aid in various categories of aid that are different from the regional aid as well as the amount in denars of the granted state aid in various categories of aid that are different from the regional aid.

T a b le 14

Granted state aid in 2017 other than regional aid (denars)

\begin{tabular}{|c|c|c|c|c|}
\hline $\begin{array}{c}\text { Horizontal } \\
\text { aid }\end{array}$ & $\begin{array}{l}\text { Environ- } \\
\text { mental } \\
\text { protec- } \\
\text { tion }\end{array}$ & $\begin{array}{l}\text { Aid for the } \\
\text { promotion } \\
\text { of projects } \\
\text { of signifi- } \\
\text { cant eco- } \\
\text { nomic } \\
\text { interest }\end{array}$ & $\begin{array}{l}\text { Aid of } \\
\text { minor } \\
\text { importance } \\
\text { (de mini- } \\
\text { mis) }\end{array}$ & Total \\
\hline
\end{tabular}

193.444.650 5.000.000 77.583.480 670.107.150 946.135.280

From the Table 14 it can be seen that the total granted state aid for 2017 which is different from the regional aid is $15,384,313$ EUR.

In respect of the instruments granting state aid for which notifications have been submitted and which is approved by a decision of the Commission in 2017, the report states that the aid is granted through instrument A (grants, subsidies, relief and exemption of taxation and social security contributions).

\subsubsection{State aid for environmental projects in Macedonia}

According to the data provided in the 2017 Annual Report of Macedonia, state aid for environmental protection planned in the amount of MKD 5,000,000 has been approved based on the $2017 \mathrm{En}-$ vironmental Investment Programme. More specifically, this is the measure for Stimulating Educational, Research and Development Studies, Programmes, Projects and Other Similar Activities for Protection and Promotion of the Environment and Nature, which forms part of the aforementioned Programme, and which the Commission for Protection of Competition has assessed to be a horizontal state aid, i.e. state aid for environmental protection in accordance with Article 15 and Article 22 of the Regulation on the Conditions and Procedure for Granting State Aid ("Official Gazette of the Republic of Macedonia" no. 03/14), only in cases of financing studies, programmes, projects and other similar activities for use of renewable energy sources. The total amount of approved state aid of MKD 5,000,000 makes $0.27 \%$ of the total amount of state aid approved for 2017.

According to the legislation on state aid, horizontal state aid can also be granted in the area of environmental protection (Article 4 paragraph (1) 
item 14 of the Law on Control of State Aid, and Articles 2 and 15 of the Regulation on the Conditions and Procedure for Granting Horizontal State Aid), whereby such aid is allowed for:

- companies which implement higher environmental protection standards in line with the national legislation on environmental protection or which increase the level of environmental protection in the absence of binding standards (investment aid) ;

- acquiring new transport vehicles exceed the binding standards or increase the level of environmental protection in the absence of binding standards; ards;

- early implementation of the binding stand-

- energy saving;

- renewable energy sources;

- combined production and central heating;

- environmental protection studies;

- waste management;

- rehabilitation of contaminated sites;

- allocation of companies; and

- in the form of reduction or exemption from payment of environmental protection fees.

Concerning the different types of measures designed for the purpose of environmental protection (from the abovementioned), there are separate rules and different intensity of the aid expressed in percentages which is allowed to be granted to the companies in accordance with the Regulation on the Conditions and Procedure for Granting Horizontal Aid. However, in general, the companies can get state aid for environmental protection if they implement standards which are higher than the existing ones in the national legislation, or if they increase the level of environmental protection in the absence of binding standards.

\section{SUMMARIZING THE COMMON AND DIFFERENT ELEMENTS THAT EMERGE FROM THE COMPARATIVE ANALYSIS OF THE ANNUAL REPORTS FOR THE COUNTRIES NAMED ABOVE}

Not taking into account the fact that each country has its own scheme of preparation of the annual report, however from the comparative analysis of the annual reports to the countries that were part of our focus of analysis, can be seen/ identified common and different elements that are characteristics of preparing the annual reports by the institutions responsible for state aid evaluation and supervision.
As common elements appearing in the annual reports prepared by the institutions of the countries that were target of our analysis, are general issues related to the area of state aid such as: the explanation of the basic concepts in the area of state aid as well as the methodology for preparing the annual report. Then a common feature is a brief introduction of state aid legislation of each country through the annual report, the instruments on which the state aid is granted and the percentage of state aid participation in relation to GDP and so on.

Except for the above common elements which constitute the annual reports of the countries that were the focus of our analysis, those same annual reports contain elements that, in the case of their comparison it can be seen the diversity and specificity when attempting to considerate and to analyze. In this analysis of the annual reports of the countries that were the focus of our interest, the following are their differences and specifics:

1. The annual report in Serbia is prepared by the State Aid Department as an independent organizational unit within the Ministry of Finance, i.e. the annual report is prepared by the State Aid Commission. In Albania, the annual report is prepared by the Department/Directorate of Economic and Development Policy of the Ministry of Finance and Economy and the State Aid Commission. In Macedonia, the annual report is prepared by the Commission for Protection of Competition as an independent body responsible for the area of competition and state aid.

2 Because of comprehensiveness, the annual reports of state aid in Serbia and Albania contain comparative data for the several previous years, which is not the case with the annual report of state aid in Macedonia. The Commission for Protection of Competition of Macedonia has compiled the annual report by 2012 in a similar way as they are composed by Serbia and Albania, but after that year such a variant of preparing annual reports of state aid was abandoned by the Commission for Protection of Competition.

3. The annual reports in Serbia and Albania are compiled based on several macroeconomic parameters, i.e. socio-economic indicators such as the participation of state aid in public expenditure, state aid per employee, as well as state aid per capita, which is not the case in conceptualizing the annual state aid report in Macedonia that contains data on the percentage of state aid participation relative to GDP. This limitation in the conceptualization of the annual state aid report is mainly due to insufficient macroeconomic data, i.e. socio-economic indicators 
that the Commission for Protection of Competition does not have when it works on the preparation of the annual report. In case of intending to draft a report in the future and what kind of data by the Commission for Protection of Competition, we think it is desirable to sign a memorandum of cooperation with the State Statistical Office, from which a memorandum of cooperation would result in its obligation to submit such data to the CPC, which the CPC would use to conceptualize and expand the annual report and what of information.

4. The annual state aid reports of Serbia and Albania contain data on granted state aid to the economic sectors (mining, public services, public transport, energy etc.), while in the annual report of Macedonia there are no other sectors, other than the tourism sector that the CPC would approve the planned measures for granting state aid and other types of economic sectors other than tourism.

5. State aids in Serbia and Albania are also granted to the fields of culture and sport, which in Macedonia these fields are beyond the approval, control and supervision by the Commission for Protection of Competition.

6. In each category of state aids, in the annual reports of Serbia and Albania, the total amount of the granted state aid per specific aid category is also calculated in percent, i.e. what is the amount in percent of the granted state aid compared to the overall granted state aid. Such a method of calculating percentages is missing in the annual state aid report in Macedonia.

7. The annual reports of Serbia and Albania have detailed and tabular data on each aid category and type of state aid about the amount of the granted state aid as well as what is the amount in percent compared to the total amount of the granted state aid.

8. In relation to one parameter the annual report of Albania differs from the annual reports of the other two countries that are the focus of our analysis. Essentially, the annual report of Albania contains data on state aid compared to the member states of EU, with the parameter illustrated in a table.

9. The annual report of Macedonia differs from the annual reports of the other two countries that are analyzed. Essentially, the annual report of Macedonia contains data on the number of decisions and opinions that were adopted during 2017 as well as that the annual report contains data on the planned/ approved state aid and data on the granted state aid after its approval.
10. The annual report of Serbia differs from the annual reports of the other two countries that are analyzed. Essentially, in the annual report of Serbia, the total granted state aid is calculated together with the state aid granted to the field of agriculture and fisheries.

11. The annual report of Albania also differs from the annual reports of the other two countries. The annual report of Albania in a tactful and textual way states the approved aid schemes as well as having sufficient data on the total granted state aid based on the approved schemes in terms of the number of users (enterprises), i.e. the number of persons employed by such measures.

\section{CONCLUSIONS AND NEXT DESIRABLE STEPS TO ACHIEVE THE OBJECTIVE}

The comparative analysis made for the annual reports of the three countries mentioned above resulted in additional experience and knowledge that give a certain picture of the development of state aid at regional level. The field of state aid if seen in isolation within a particular state, and missing the possibility of greater development due to the lack of the element of bilateral and multilateral regional cooperation between the different countries in the region.

Although the area of competition and state aid are closely linked, nevertheless taking into account the present circumstances, the area of competition is much more advanced in terms of regional cooperation compared to the area of state aid which lacks regional cooperation between state institutions responsible for this area. Such a lack of regional cooperation between the institutions in the area of state aid results in no representation of regional development of the area in general, but also to the inability to exchange experiences and knowledge on a regional level which is a handicap for the regional development of this area with joint forces.

The activities undertaken in order to sign a Memorandum of Cooperation between the institutions of the different countries that are responsible for this area, at regional level would improve the picture of the state aid area in general, but would also help to avoid its isolation as an area, i.e. to see itself only within a particular state.

Seen from another angle, the regional cooperation and exchange of experience is lacking for each employee working in the state aid area. Initially, signing a Memorandum of Cooperation would open 
up possibilities for an institutional bilateral and multilateral regional cooperation, which could potentially lead the cooperation to move to higher level with possible establishment of a forum (network or body) for regional cooperation between the employees of our institutions, and that would undoubtedly contribute to the exchange of knowledge and experiences among employees, but also to bring the area of state aid to the level where the competition field now stands. If the same regional development were achieved in the area of state aid, it would be a great benefit for the competent institutions as well as for the employees as part of such institutions.

All parts involved would benefit if institutional initiative for cooperation in the field of state aid were taken, whereby signing the Memorandum of Cooperation between the countries in the region may be the first step in initiating such cooperation.
Finally, state aid for environmental project and issues in general is minor in all 3 analyzed countries. Having in mind growing environmental awareness among the citizens, as well as real threats of climate changes for the region, governments in the region have to allocate much more resources for developing green energy projects, environment protection activities and recycling resources capacities.

\section{REFERENCES}

Annual report of the CPC 2017 year, according the Law on State Aid Control in the Republic of Macedonia ( Official Gazette, No 145/2010).

Annual report of the CPC 2017 year, according the Law State Aid Control in the Republic of Serbia (Official Gazette, No. 51/09, 73/19).

Annual report of the CPC 2017 year, according the Law State Aid Control in the Republic of Albania (Official Gazette, No.4/2015). 
